\title{
Using Augmented Reality (AR) for Enhancing Chinese Vocabulary Learning
}

\author{
https://doi.org/10.3991/ijet.v15i17.15161
}

\author{
Thanakorn Uiphanit ${ }^{\bowtie}$, Jirayu Unekontee, Natcha Wattanaprapa, Premkamon \\ Jankaweekool, Wilailuk Rakbumrung \\ Suan Sunandha Rajabhat University, Bangkok, Thailand \\ thanakorn.ui@ssru.ac.th
}

\begin{abstract}
This research aims to develop a mobile AR application for enhancing Chinese vocabulary learning to students who learn Chinese as a main subject. The requirement was gathered from Chinese teachers by interview to assess a suitable content and educational technology for students. The result showed that augmented reality is the best choice. Then, 3D model, illustration, sound was drawn based on the contents and the software design and implementation were performed. After finishing this development process, Grade 10th students majoring in Chinese, at School A, Ang Thong provience. tested this application. The evaluation process was performed using pretest and posttest data analyzed by a paired samples t-test at a $95 \%$ confidence level. The result of this study shows that the application is an efficient tool to help students improve their learning capabilities.
\end{abstract}

Keywords-Augmented reality, Application, 3D Model, Chinese vocabulary.

\section{Introduction}

China is well-known and widely used not just in China, but also in Asia and even the whole world. At present, China has played important roles in import/export and economic aspects in the global scale as well as is a part of worldwide business investment between countries in Asia like Thailand. Chinese language is the most important subject for Grade 10th students majoring in Chinese. Additionally, it is also an important elective subject for all non-Chinese students in every school. Although the Chinese language is important, not many students are excited to study this language [8] because they perceive Chinese vocabulary as complicated, boring, and difficult to learn and memorize.

Based on the problem defined above, three Chinese teachers are interviewed. The outcomes from these interviews are various opinions related to the focusing problem and their suggested solutions.

Currently, many teaching techniques and various materials in learning Chinese are available over the Internet, especially on youtube.com[5], web application[3], digital flash card[16], digital game[13], and mobile application[9]. This learning materials 
and platforms point out the advantage for teaching with media is better for enhancing the vocabulary learning than lecture.

AR (Augmented reality) is a new educational technology and powerful for increasing accessible to young users. [10],[11],[14] especially in learning Chinese [2] because AR has integrated between virtual and reality environments closely [6]. Therefore, AR application for enhancing Chinese vocabulary learning has been developed to be used in this research as a tool to improve students memorize of Chinese vocabulary and academic achievement as well as to activate enthusiasm in students [1]. Most other types of existing learning materials are still lacking ability to establish userfriendly experience to users, not as good as learning with application. [7],[9],[12].

\section{Objective}

a) To design and develop an augmented reality application for enhancing Chinese vocabulary learning.

b) To compare the academic achievement for students before and after learning with the augmented reality application.

c) To study student satisfaction after learning with the augmented reality application.

\section{Research Framework}

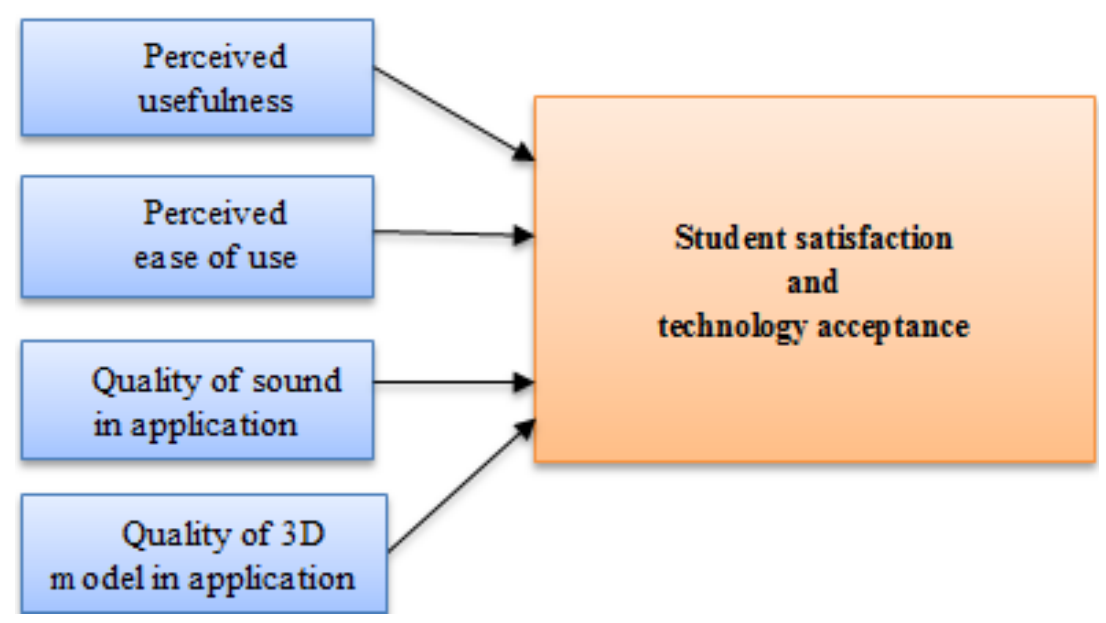

Fig. 1. The conceptual model for learning with the augmented reality application [4], [7]

Accordingly, Fig. 1, the conceptual model of this study, shows that the main target of this study is Grade 10th students majoring in Chinese. Additionally, the objective of this study is the academic achievement of students that can be measured by their test scores in each vocabulary difficulty level. Moreover, another outcome that can be obtained is the positive attitude of students who learn by seeing this 3D model and 
listening sound of this word from AR card. Thus, the stimulus in this experiment is an augmented reality application.

\section{$4 \quad$ Research Methodology}

\subsection{Experimental design}

In this study, an experiment was conducted on Grade 10th students majoring in Chinese, at School A, Ang Thong provience. This experiment aims to evaluate the students' attitudes, including their academic achievement, toward the Chinese vocabulary, which is a part of the fundamental of Chinese course.

This experiment consists of 5 steps. In the first step, students are administered a pretest. Second, the augmented reality application is introduced to them in a classroom. Third, students are administered a posttest. Fourth, questionnaires are given to the students for inquiry of satisfaction after using the application. Lastly, data are analyzed to check for the effectiveness of learning with the augmented reality application.

\subsection{Participants}

To determine the objectives of this research, 40 participants, all of whom Grade 10th students majoring in Chinese, with the average age of 16 years old, are sampled. These samples consist of 15 males and 25 females; none of them has been enrolled in Chinese courses or has a background in Chinese. Additionally, the application is introduced to students in the classroom as the control environment of this experiment. Therefore, there is no external influencer towards samples until the experiment is terminated.

\subsection{Materials}

There are three materials necessary for this experiment: an augmented reality application, academic-achievement tests, and a student satisfaction questionnaire.

Details of each component are described below.

a) Augmented Reality application: The objective of the application is to stimulus the students to attention in Chinese lesson and more practice for memorize the vocabulary. In this process, the student's memorizing the vocabulary in each category can be developed with enjoyment.

b) Academic achievement tests: There are two testing forms in this experiment: a pretest and a posttest. The purpose of the pretest exam is to measure students' knowledge in Chinese vocabulary before learning, while the posttest exam aims to measure the success of the learning outcomes after learning with application.

c) Student satisfaction questionnaire: Since the application is developed for students' self-learning, the attraction from the application must be measured using the 
satisfaction index from students. The satisfaction score is a Likert scale with 5 levels, ranging from 1 to 5 . The meaning of each score is listed below so that the analysis of student satisfaction can be performed [15].

- $1.00-1.80=$ strongly disagree

- $1.81-2.60=$ disagree

- $2.61-3.40=$ neither agree nor disagree

- $3.41-4.20=$ agree

- $4.21-5.00=$ strongly agree

The design and development of this game is a 3D augmented reality application that consists 3D model, marker, Details of the application system flow in Figure 2.

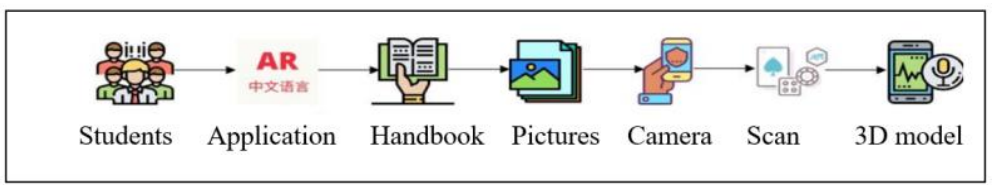

Fig. 2. System flow in the 3D augmented reality application

Accordingly, Fig. 2, the system flow in the 3D augmented reality application, shows that the main target of this study is Grade 10th students majoring in Chinese. Additionally, the objective of this study is the academic achievement of students that can be measured by their test scores in each vocabulary difficulty level. Moreover, another outcome that can be obtained is the positive attitude of students who learn by seeing this 3D model and listening sound of this word from AR card. Thus, the stimulus in this experiment is an augmented reality application. Details of the screens follow in Table 1.

Table 1. Description of 3D augmented reality application

\begin{tabular}{|c|c|}
\hline Figure & Description \\
\hline & \\
\hline
\end{tabular}




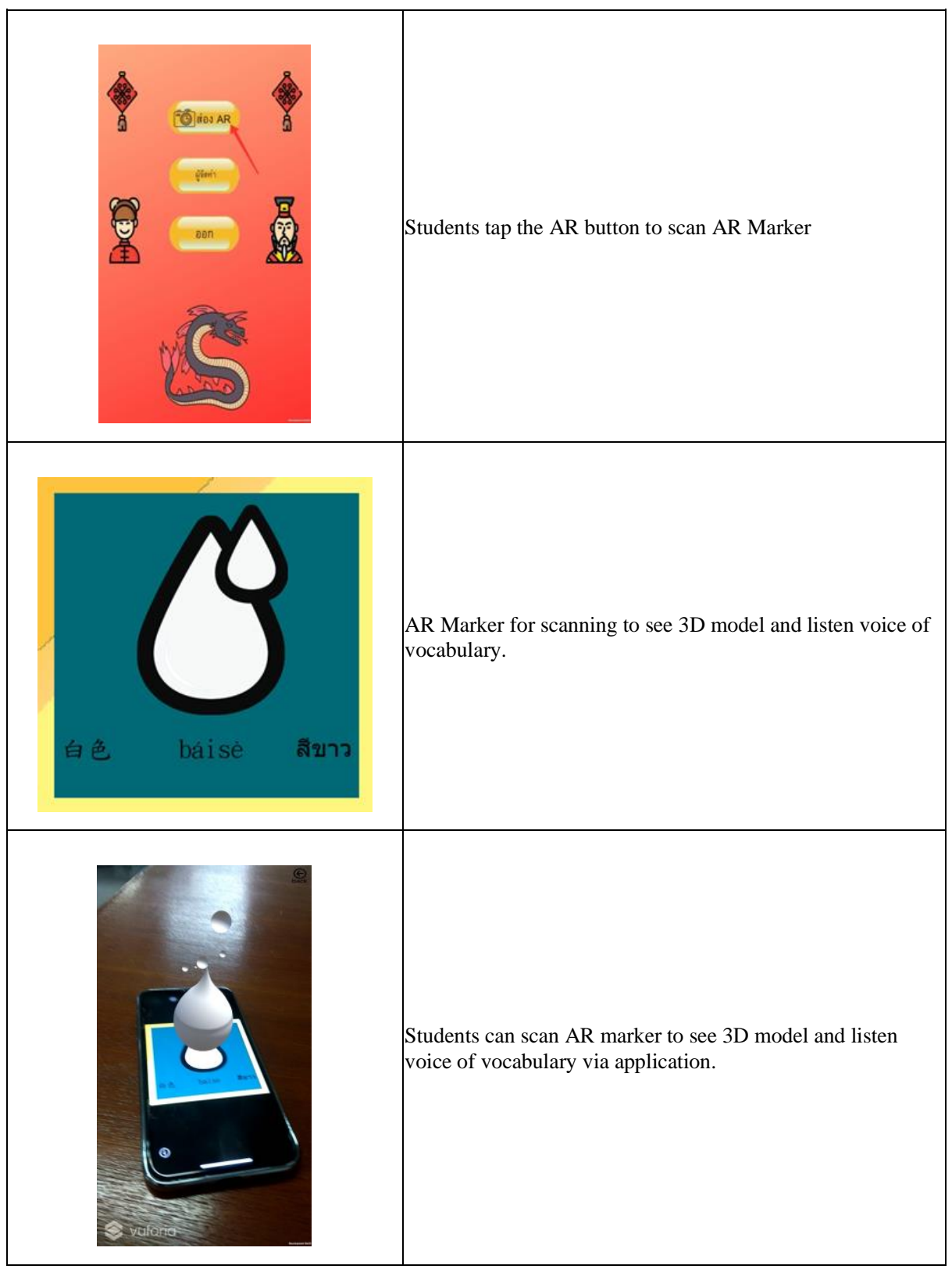

\section{$5 \quad$ Findings}

The academic achievement test is based on the pretest and the posttest to compare the students' understanding before and after learning with application [13]. Moreover, the analysis to answer this hypothesis is the paired t-test with a $95 \%$ confidence level. 
To test the effectiveness of learning with the game, the paired samples t-test is applied. The results are presented in Table 2 .

Table 2. Paired samples t-test of posttest - pretest data

\begin{tabular}{|l|c|c|c|c|c|}
\hline & Number $(\mathbf{N})$ & Mean $(\overline{\boldsymbol{x}})$ & S.D. & t & Sig. \\
\hline Post - Pre & 40 & 2.73 & 5.228 & 3.297 & .002 \\
\hline
\end{tabular}

The t-test shows that the differences of means from both tests are highly significant $(\mathrm{p}<0.05)$. Thus, these differences indicate that students can improve their learning skill and increase their achievements after learning with application. Therefore, we can claim that the students' achievement can be achieved when they learning with AR application.

Table 3. Student satisfaction and technology acceptance after learning with the application

\begin{tabular}{|c|c|c|c|c|}
\hline No & Question & Mean & S.D. & Interpreted \\
\hline \multicolumn{5}{|c|}{ Perceived usefulness } \\
\hline 1 & $\begin{array}{l}\text { Can using application help the } \\
\text { learners to study better? }\end{array}$ & 4.33 & 0.83 & Strongly agree \\
\hline 2 & $\begin{array}{l}\text { Can using application help learners } \\
\text { to understand better than lecture } \\
\text { teaching? }\end{array}$ & 4.23 & 1.00 & Strongly agree \\
\hline \multicolumn{5}{|c|}{$\begin{array}{r}\text { Perceived ease of use } \\
\end{array}$} \\
\hline 3 & $\begin{array}{l}\text { Is the application easy to install and } \\
\text { implement? }\end{array}$ & 3.70 & 0.65 & Agree \\
\hline 4 & $\begin{array}{l}\text { Is the application good to response } \\
\text { and suitable? }\end{array}$ & 3.78 & 0.77 & Agree \\
\hline 5 & Is the application fast to process? & 3.90 & 0.67 & Agree \\
\hline 6 & $\begin{array}{l}\text { Are in-application instructions easy } \\
\text { to understand? }\end{array}$ & 4.25 & 0.81 & Atrongly agree \\
\hline \multicolumn{5}{|c|}{ Quality of sound in application } \\
\hline 7 & $\begin{array}{l}\text { Are in-application sound easy to } \\
\text { listen? }\end{array}$ & 4.23 & 0.97 & Strongly agree \\
\hline 8 & $\begin{array}{l}\text { Are in-application sound spell to } \\
\text { correct? }\end{array}$ & 4.15 & 0.77 & Agree \\
\hline 9 & $\begin{array}{l}\text { Are in-application sound spell to } \\
\text { clear? }\end{array}$ & 4.08 & 0.80 & Agree \\
\hline \multicolumn{5}{|c|}{ Quality of $3 D$ model in application } \\
\hline 10 & $\begin{array}{l}\text { Is the in-application } 3 \mathrm{D} \text { model } \\
\text { illustration beautiful, attractive and } \\
\text { interesting? }\end{array}$ & 4.18 & 0.87 & Agree \\
\hline 11 & $\begin{array}{l}\text { Is the in-application 3D model size } \\
\text { suitable? }\end{array}$ & 4.00 & 1.18 & Agree \\
\hline 12 & $\begin{array}{l}\text { Is the in-application 3D model } \\
\text { output stable? }\end{array}$ & 4.38 & 0.84 & Strongly agree \\
\hline
\end{tabular}

Table 3 shows relationships between the quality of application and application acceptance. Though each data belongs to each part, there are some relations among 
these data that can be analyzed and to be disclosed to indicate the consequences to learners, both strongly agree and agree. The result indicates that the mean score of perceived usefulness is highest. The second is the quality of 3D model in application. The third is the quality of sound in application. Besides, the perceived ease of use is the lowest. Thus, the application is able to help students to pay more attention in the learning process and understand clearly.

Consequently, these results are consistent with the collected data that students have positive attitudes towards the learning by application.

\section{Discussion and Conclusions}

According the literature, not all types of learning materials are suitable for every learning context. Some materials may be time consuming [3], while some materials can be useful only to small groups of learners [3][5]. This research aims to solve this problem.

To achieve the objective of this research, to develop a mobile application for enhancing Chinese vocabulary learning, an AR application was designed, developed and evaluated. In the design process, to promote students' excite and attention, students generally see vocabulary with 3D model and listen sound of vocabulary in a real time Thus, they can memorize the vocabulary easier than learning by vocabulary repetition so that the time-consuming problem is solved. In addition, this application allows multiple learners. Thus, the small-group problem is also solved.

The target sample group is students in the Grade 10th students majoring in Chinese, at School A, Ang Thong provience. The outcome of this research is the students' academic achievement when they learn the Chinese vocabulary through the AR mobile application, especially in the five vocabulary categories.

Thus, this AR application is practical and suitable for enhancing Chinese vocabulary learning in Chinese subject. Moreover, the relationships among students' achievement factors are consistent and obviously be seen. Therefore, the proposed model can support students' learning skills and push the students' interest in Chinese vocabulary as expected.

\section{$7 \quad$ References}

[1] Aldalalah, O. M., Ababneh, Z., Bawaneh, A., \& Alzubi, W. (2019). Effect of Augmented Reality and Simulation on the Achievement of Mathematics and Visual Thinking Among Students. International Journal of Emerging Technologies in Learning (iJET), 14(18), 164185. https://doi.org/10.3991/ijet.v12.i11.7354

[2] Chen, C. H., \& Su, C. C. C. (2013). An integrated design flow in developing an augmented reality game for enhancing children chinese learning experience. International Journal of Digital Content Technology and its Applications, 7(4), 907. https://doi.org/10.4156/jdcta. vol7.issue4.109. 
[3] Chen, H. Y., \& Liu, K. Y. (2008). Web-based synchronized multimedia lecture system design for teaching/learning Chinese as second language. Computers \& Education, 50(3), 693-702. https://doi.org/10.1016/j.compedu.2006.07.010

[4] Chou, Y. S., Hou, H. T., Yu, M. C., Lee, H. J., Wu, H. S., Yang, Y. T., \& Liao, Y. J. (2012). Running Tommy@: Developing a Digital Adventure Game Based on Situated Learning to Promote Learners' Concepts of Earthquake Escape. In Digital game and intelligent toy enhanced learning (DIGITEL), 2012 IEEE fourth international conference on pp. 156-158. https://doi.org/10.1109/digitel.2012.44

[5] Hwang, J. L. (2010, June). University EFL students' learning strategies on multimedia YouTube. In EdMedia+ Innovate Learning (pp. 3611-3620). Association for the Advancement of Computing in Education (AACE).

[6] Li, Q. M., Chen, Y. M., Ma, D. Y., Huang, C., Xu, S., Lu, R. M., ... \& Wang, X. C. (2011, June). Design and implementation of a chinese character teaching system based on augmented reality interaction technology. In 2011 IEEE International Conference on Computer Science and Automation Engineering (Vol. 2, pp. 322-326). IEEE. https://doi.org/10.11 09/csae.2011.5952479

[7] Li, Y., Guo, A., Chin, C. L., \& Lim, J. H. (2016). A platform for creating Smartphone apps to enhance Chinese learning using augmented reality. Scientific Phone Apps and Mobile Devices, 2(1), 1-12. https://doi.org/10.1186/s41070-016-0007-4

[8] Kanoksilapatham, B. (2011). National survey of teaching Chinese as a foreign language in Thailand. Southeast Asian Ministers of Education Organization.

[9] Kuo, J. H., Huang, C. M., Liao, W. H., \& Huang, C. C. (2011, September). Huayu Navi: A mobile Chinese learning application based on intelligent character recognition. In International Conference on Technologies for E-Learning and Digital Entertainment (pp. 346354). Springer, Berlin, Heidelberg. https://doi.org/10.1007/978-3-642-23456-9 63

[10] Nuanmeesri, S. (2018). The augmented reality for teaching Thai students about the human heart. International Journal of Emerging Technologies in Learning (iJET), 13(06), 203213. https://doi.org/10.3991/ijet.v13i06.8506

[11] Radu, I. (2014). Augmented reality in education: a meta-review and cross-media analysis. Personal and Ubiquitous Computing, 18(6), 1533-1543. https://doi.org/10.1007/s00779-01 3-0747-y

[12] Santos, M. E. C., Taketomi, T., Yamamoto, G., Rodrigo, M. M. T., Sandor, C., \& Kato, H. (2016). Augmented reality as multimedia: the case for situated vocabulary learning. Research and Practice in Technology Enhanced Learning, 11(1), 4. https://doi.org/10.1186/s4 1039-016-0028-2

[13] Syson, M. B., Estuar, M. R. E., \& See, K. T. (2012, December). Abkd: Multimodal mobile language game for collaborative learning of Chinese Hanzi and Japanese kanji characters. In 2012 IEEE/WIC/ACM International Conferences on Web Intelligence and Intelligent Agent Technology (Vol. 3, pp. 311-315). IEEE. https://doi.org/10.1109/wi-iat.2012.65

[14] Tezer, M., Yıldız, E. P., Masalimova, A. R., Fatkhutdinova, A. M., Zheltukhina, M. R., \& Khairullina, E. R. (2019). Trends of Augmented Reality Applications and Research throughout the World: Meta-Analysis of Theses, Articles and Papers between 2001-2019 Years. International Journal of Emerging Technologies in Learning (iJET), 14(22), 154174. https://doi.org/10.3991/ijet.v14i22.11768

[15] Uiphanit, T., Bhattarakosol, P., Suanpong, K., \& Iamsupasit, S. (2019). Packet Warriors: An Academic Mobile Action Game for Promoting OSI Model Concepts to Learners. International Journal of Interactive Mobile Technologies (iJIM), 13(06), 41-51. https://doi.org/ $\underline{10.3991 / \text { ijim.v13i06.10469 }}$ 
[16] Zhu, Y. (2010). Rediscovering the impacts of digital flashcard on Chinese character memorization of beginning US learners. Chinese Teaching in the World, 1, 127-137.

\section{Authors}

Thanakorn Uiphanit is currently a lecturer in Department of information science, Faculty of Humanities and Social Science, Suan Sunandha Rajabhat University, Bangkok, Thailand. E-mail: thanakorn.ui@ssru.ac.th

Jirayu Unekontee is currently an undergraduate student in Department of information science, Faculty of Humanities and Social Science, Suan Sunandha Rajabhat University, Bangkok, Thailand. E-mail: $\underline{\text { S59123457020@ssru.ac.th }}$

Natcha Wattanaprapa is currently a lecturer in Department of information science, Faculty of Humanities and Social Science, Suan Sunandha Rajabhat University, Bangkok, Thailand. E-mail: natcha.wa@ssru.ac.th

Premkamon Jankaweekool is currently a lecturer in College of Innovation and Management, Suan Sunandha Rajabhat University, Bangkok, Thailand. E-mail: premkamon.ja@ssru.ac.th

Wilailuk Rakbumrung is currently a lecturer in College of Innovation and Management, Suan Sunandha Rajabhat University, Bangkok, Thailand. E-mail: Wilailuk.ra@ssru.ac.th

Article submitted 2020-04-22. Resubmitted 2020-05-23. Final acceptance 2020-05-26. Final version published as submitted by the authors. 